\title{
Cyclic channel-shoal dynamics at the Ameland inlet: the impact on waves, tides, and sediment transport
}

\author{
Klaas J. H. Lenstra ${ }^{1}$ (D) . Stefan R. P. M. Pluis ${ }^{1,2} \cdot$ Wim Ridderinkhof $^{1,3} \cdot$ Gerben Ruessink $^{1} \cdot$ Maarten van der Vegt $^{1}$
}

Received: 17 July 2018 / Accepted: 17 January 2019 / Published online: 27 February 2019

(C) The Author(s) 2019

\begin{abstract}
Ebb-tidal deltas are shallow features seaward of tidal inlets, acting as a wave filter for the nearby barrier island and a source of sediment for the landward tidal basin. On many ebb-tidal deltas, channels rotate and shoals periodically attach to the downdrift island. This cyclic behavior can also include an alternation between one- and two-channel inlet configurations. The effect of the long-term ( $>$ years) cyclic behavior on the short-term patterns of waves, tidal currents, and sediment transport is unknown. Here, we use Delft3D/SWAN models to simulate the Dutch Ameland tidal inlet during four phases of the cycle to show that many of the physical processes on the ebb-tidal delta and in the entire tidal system are affected by the cyclic evolution of channels and shoals. In particular, the periodic variations in the channel positions appear to significantly influence the tidal asymmetry in the inlet and mean flow characteristics. As a result, the net sediment exchange between basin and sea is cyclic and follows the periodicity of the one- and two-channel inlet configuration. Moreover, we find that the wave energy dissipation on the ebb-tidal delta is enhanced by a shallow shoal or an updrift-oriented ebb-channel, which shields the coast from the incoming waves. Our results demonstrate how the cyclic channel-shoal dynamics at natural tidal inlets is likely to affect the safety functions of the ebb-tidal deltas, varying the offshore wave energy dissipation as well as adjusting the sediment pathways on the ebb-tidal delta.
\end{abstract}

Keywords Ebb-tidal delta $\cdot$ Wave energy $\cdot$ Tidal asymmetry $\cdot$ Sediment transport $\cdot$ Cyclic behavior

\section{Introduction}

Tidal inlets connect back-barrier basins to the adjacent sea and facilitate the exchange of sediment. In periods of sea level rise, the net import of sediment is important for the long-term stability of back-barrier basins to preserve the morphology of the basins. For example, insufficient sediment import may result in loss of salt marsh and tidal flat area (Dissanayake et al. 2012) and thus threaten local ecosystems. Data suggest that most tidal inlets of the Dutch

Responsible Editor: Emil Vassilev Stanev

Klaas J. H. Lenstra

k.j.h.lenstra@uu.nl

1 Department of Physical Geography, Faculty of Geosciences, Utrecht University, P.O. Box 80.115, 3508, TC Utrecht, The Netherlands

2 Rijkswaterstaat, Griffioenlaan 2, Utrecht, The Netherlands

3 Witteveen + Bos, Van Twickelostraat 2, Deventer, The Netherlands
Wadden Sea are importing sediment that is provided by ebbtidal deltas (Elias et al. 2012). Ebb-tidal deltas are shallow features at the seaward side of tidal inlets and are formed by the joint action of waves and tides (Hayes 1975). Many ebb-tidal deltas have a cyclic evolution, featuring a rotation of channels and formation of sandy shoals that migrate and attach to the downdrift coast (Fitzgerald 1984; FitzGerald et al. 2000; Ridderinkhof et al. 2016).

De Swart and Zimmerman (2009) reviewed tidal inlet systems and the relevant processes and morphodynamics. Most studies on the exchange of sediment between basin and sea have focused on the basin geometry but not on the ebb-tidal delta (Speer and Aubrey 1985; Friedrichs and Aubrey 1988). Shallow areas are known to affect this exchange; basins with a large tidal range over depth ratio tend to be flood-dominant, while large intertidal areas cause ebb-dominant sediment transport. While we have a good understanding on how the basin geometry influences tidal asymmetry, the role of the cyclic changes of the shallow ebb-tidal delta on tidal wave deformation has not been studied. Tides also cause mean flows that can result in net import/export of sediment. For example, when tides have a 
(partly) progressive character in isolated basins, the Stokes return flow will result in export of sediment. Mean flows can also be generated by tide-topography interactions due to the presence of channels and shoals (Ridderinkhof 1988). Therefore, it is expected that the cyclic evolution of ebbtidal deltas influences both the mean flow patterns and tidal asymmetry at many locations.

Many studies on tidal inlet systems have neglected the effect of waves (Van Leeuwen et al. 2003; Van der Vegt et al. 2006, 2009; Dissanayake et al. 2012). However, ebbtidal deltas are not only a source of sediment for the back-barrier basin, but also a filter for offshore incident wave energy. Waves propagate and dissipate their energy by means of bottom friction and wave breaking on the ebb-tidal delta, which thus protects the coasts and backbarrier basin (FitzGerald 1988; Van der Westhuysen 2012; Elias and Hansen 2013). Furthermore, waves can drive flows and are able to entrain sediment which can be transported by currents. Therefore, waves are important for the sediment transport near tidal inlet systems (Nahon et al. 2012; Ridderinkhof et al. 2016). Wave energy dissipation strongly depends on the relative wave height (wave height divided by water depth) and waves can refract over the shoals. It is therefore expected that the changes in location of channels and shoals influence the wave energy patterns not only on the ebb-tidal delta but also in the inlet. For example, Hansen et al. (2013) have shown that the nearshore wave dynamics near a tidal inlet have changed as a response to the large-scale contraction of the nearby ebb-tidal delta. Herrling and Winter (2014) have studied the hydrodynamics and sediment transport at an ebb-tidal delta in the German Wadden Sea and have shown that the sediment pathways during storm are significantly different from calm, tidedominated conditions.

The aim of this paper is to study how the cyclic behavior of the ebb-tidal delta influences the tide and wave dynamics and the sediment transport patterns. We addressed this aim by using the Ameland Inlet as a case study. This is a tidal inlet system that has a clear cyclic evolution with a typical period of 50-60 years (Israel and Dunsbergen 1999); has good data availability on bathymetry and wave conditions; has only minimally connectivity to adjacent tidal basins such that it can be considered an isolated system (Ridderinkhof 1988; Cheung et al. 2007; Dissanayake et al. 2012); and it is the least disturbed system of the Dutch Wadden Sea (Elias et al. 2012). We used a modeling approach in which we calculated waves, flow and sediment transport for four different phases of the cyclic evolution. The wave climate was represented by 21 wave classes based on wave height and direction, and results were combined into yearly mean sediment transport patterns. The simulations allowed us to discriminate between effects of changes in tide-driven flows, waves and changes in position of the channels and shoals. We proceed by describing in more detail the dynamics of Ameland Inlet (Section 2.1), the model (Section 2.2) and the simulations performed (Section 2.3). The wave energy propagation and dissipation during the four phases are described in Section 3.1. Section 3.2 shows the patterns of yearly mean sediment transport, where a distinction between the effect of waves and tides is made. The results are discussed in Section 4 and the conclusions are in Section 5.

\section{Material and methods}

\subsection{Ameland Inlet}

Israel and Dunsbergen (1999) described four typical phases of the morphological cycle at the Ameland Inlet (Fig. 1). During phase 1, there is a one-channel system in the inlet; this ebb-channel (Westgat) is oriented to the northwest (for example, 1971). A shoal near the Ameland coast originates from the ebb-tidal delta. During phase 2, the main ebbchannel (Akkepollegat) is more symmetric and in the inlet a second channel is present (1989). Furthermore, the shoal has completely merged with Ameland. During phase 3, the second channel in the inlet became deeper, the channel rotation has continued while the sediment of the shoal that attached to Ameland has been redistributed (1999). During phase 4 , the main ebb-channel is building a new extension in northwestern direction. Also, the second channel in the inlet is decreasing in size and depth while the inlet has the tendency to become narrower (2011). Additionally, a new shoal is present at the northeastern side of the ebbtidal delta. Although the patterns do not repeat exactly, the gross characteristic of channel rotation, switching between a one- and two-channel inlet system, development of a large sandy shoal and its subsequent migration towards Ameland, repeat on a typical time scale of about 50 years (Israel and Dunsbergen 1999). In the conceptual model of FitzGerald et al. (2000) this is a typical example of ebb-tidal delta breaching. This type of cyclic behavior is common for tidal inlets systems along the Dutch and German Wadden Sea (Ridderinkhof et al. 2016).

This cyclic morphodynamic evolution result from a combined forcing of tides and waves. Ameland Inlet is located in a region of mesotidal conditions with a typical semi-diurnal tidal range of $2.4 \mathrm{~m}$ at Nes near the Ameland Inlet. Diurnal inequality is relatively small. Peak water levels can be up to $3.5 \mathrm{~m}$, caused by storm surges of up to $2 \mathrm{~m}$. The Ameland Inlet has a typical width of $4 \mathrm{~km}$ and the depth of the main channel is up to $25 \mathrm{~m}$; the typical tidal prism is $400 \mathrm{Mm}^{3}$ (Sha 1989). The average offshore wave height is $1.3 \mathrm{~m}$, but can be up to $7 \mathrm{~m}$ during severe storms. The waves have an oblique 

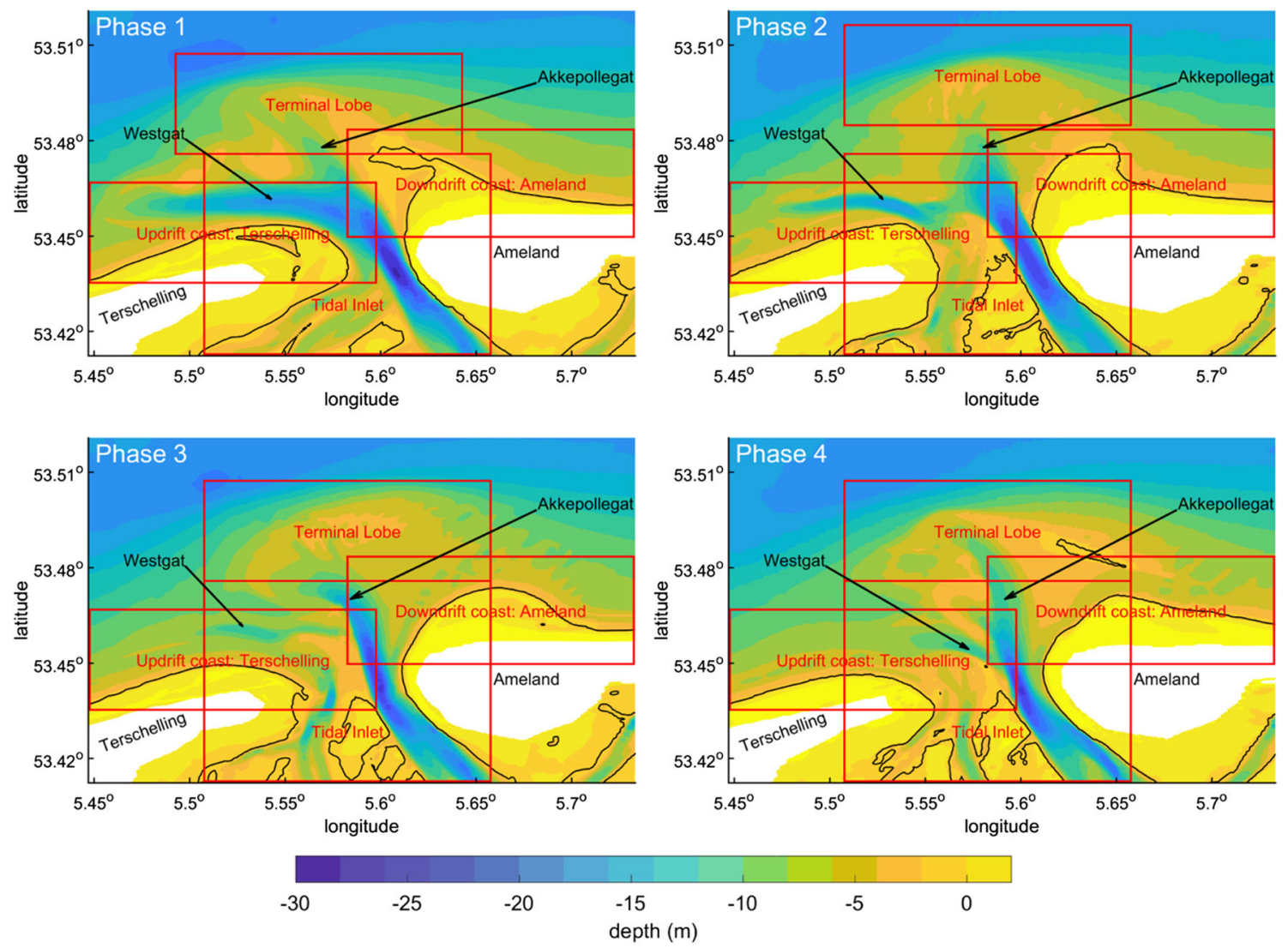

Fig. 1 Morphologic cycle of the Ameland Inlet, typical time scale is 50-60 years. Colors indicate local bathymetry in intervals of $2 \mathrm{~m}$ with black contour at $1 \mathrm{~m}$ isobath. Phase 1: one-channel system with shoal on ebb-tidal delta (1971-bathymetry). Phase 2: transition to twochannel system with shoal attaching to the coast as coherent shoal

direction and typically come from the west and northwest. The waves drive longshore transport of sediment in the order $10^{6} \mathrm{~m}^{3} /$ year (Ridderinkhof et al. 2016). The sediment is relatively fine in the basin $\left(\mathrm{d}_{50}\right.$ of $\left.60-240 \mu \mathrm{m}\right)$ and relatively coarse in the channel and on the ebb-tidal delta $(240-350 \mu \mathrm{m})$ (Wang et al. 2016).

\subsection{Modeling system}

For simulations of the hydrodynamics and sediment transport in the Ameland Inlet, the coupled modeling system of Delft3D-FLOW and SWAN was used. The numerical model Delft3D-FLOW (Deltares 2014) was applied in its $2 \mathrm{DH}$ mode, solving the depth-averaged shallow water equations on a staggered model grid. The phase-averaged wave model SWAN (Booij et al. 1999; Ris et al. 1999; Holthuijsen 2010) was employed to compute the wave energy spectrum by solving the wave action balance equation in its stationary form. The SWAN and Delft3D model were coupled with a coupling time of $20 \mathrm{~min}$. After SWAN is provided with the bed level, water level, and (1989-bathymetry). Phase 3: two-channel system with shoal distribution (1999-bathymetry). Phase 4: transition to one-channel system with a new shoal on the ebb-tidal delta (2011-bathymetry). The areas indicated in red are the four key regions discussed in Section 3.2

flow velocity by Delft3D-FLOW, it computes the spectral wave energy and wave-induced forces. Subsequently, this information is communicated to Delft3D-FLOW and used to calculate water levels, flow velocities, and sediment transport.

In Delft3D-FLOW, several parameters values were set based on model calibration. The bed roughness was prescribed with a constant Chézy friction coefficient value of $63 \mathrm{~m}^{0.5} / \mathrm{s}$. The horizontal eddy viscosity and diffusivity were $5 \mathrm{~m}^{2} / \mathrm{s}$ and $1 \mathrm{~m}^{2} / \mathrm{s}$, respectively. Furthermore, the bed consisted of homogeneous sediment $\left(\mathrm{d}_{50}=250 \mu \mathrm{m}\right)$ and bed level updates were not considered. The SWAN model did not account for wind growth and non-linear triadinteractions were not included. The default settings were employed for white-capping, bottom friction, and depthinduced breaking.

In the sediment transport module, we used the transport formulations of Van Rijn et al. (2004), which differentiate between bed and suspended load mechanisms. Unless mentioned otherwise, the default settings are used for sediment transport. In these formulations, the bed load 
Fig. 2 High resolution curvilinear flow grid covering the Ameland Inlet system, located in the north of the Netherlands. Grid lines are shown with an interval of 4 lines. Dots indicate locations of water level measurement stations (blue) and wave buoys (black)

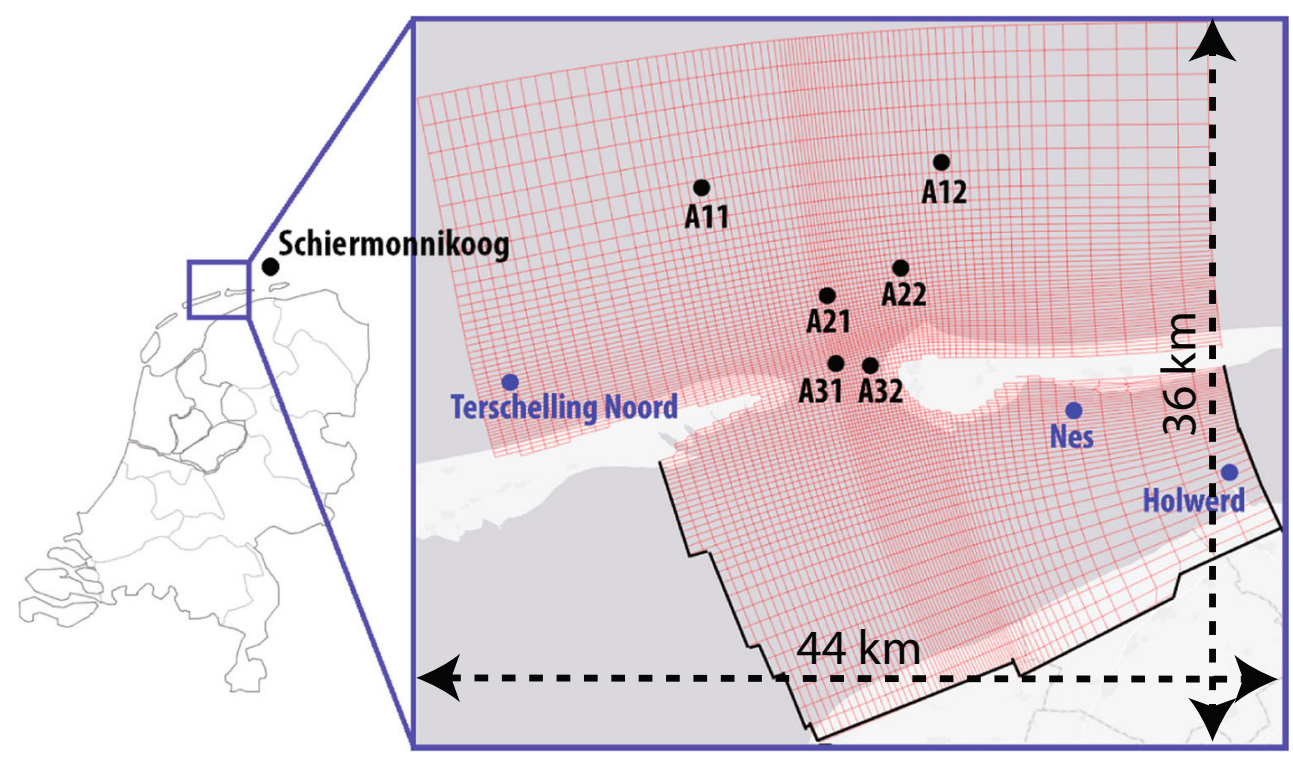

transport predictor $q_{b}$ is proportional to the instantaneous velocity of currents and waves $u$ as $q_{b} \propto u^{2.5}$. As a result, skewed waves can transport sediment in the simulations because of relatively strong orbital velocities in the crest of the wave compared to the trough. In the model, this was achieved by the parametrization of Van Rijn et al. (2004) after the method of Isobe and Horikawa (1982). The effects of wave skewness on suspended transport were considered small and therefore neglected. However, waves do influence the suspended load transport in the model simulations in two ways. Firstly, the wave-induced forces drive currents that, combined with the tidal currents, determine the advection of entrained sediment. Secondly, there is non-linear interaction between the boundary layers at the bed associated with the waves and the current, which has the effect of enhancing both the mean and oscillatory bed shear stresses. Through the use of the parameterization of Soulsby et al. (1993), the wave-current interaction model of Van Rijn et al. (2004) is applied to account for the wave-induced increase in the bed shear stress. As a result, more sediment is entrained and made available for transport by currents. The complete expressions for sediment transport can be found in Van Rijn (2007a, b).

\subsection{Model setup}

\subsubsection{Model domain}

The curvilinear computational grids (De Fockert 2008; Wang et al. 2016) cover the Ameland Inlet system (Fig. 2). To obtain more detailed results of patterns of net sediment transport, the flow grid has a factor 2 higher resolution than the wave grid. The flow grid consists of 324 and 348 cells in the east-west $(x)$ and north-south $(y)$ direction, respectively.
The grid size ranges from $300 \mathrm{~m}$ by $350 \mathrm{~m}$ near the offshore boundary up to $30 \mathrm{~m}$ by $40 \mathrm{~m}$ near the Ameland inlet. The wave grid is slightly larger than the flow grid to account for wave refraction and shadowing effects. In the east-west direction the wave grid was extended with 16 cells, making the number of grid cells 178 and 174 in $x$ - and $y$-direction, respectively. To fulfill the Courant criterion the time step of Delft3D was set at $12 \mathrm{~s}$.

Model bathymetries were assembled by interpolating measured data of sea bottom elevations onto curvilinear model grids. The measurements were conducted by the Dutch government (Rijkswaterstaat) and are publicly available via opendap.deltares.nl. To test the effect of changing ebb-tidal delta bathymetry, four different phases were based on the bathymetries of 1971, 1989, 1999, and 2011 (see Section 2.1).

\subsubsection{Boundary conditions}

The Ameland Inlet has a relatively isolated basin meaning that exchange of water over the watersheds is relatively small (Ridderinkhof 1988; Cheung et al. 2007; Dissanayake et al. 2012; Elias et al. 2015). Therefore, the boundaries landward of the inlet (indicated by the black lines in Fig. 2) were assumed to be closed and the normal component of flow and sediment transport were set to zero.

At the offshore boundaries, the model was forced by both tides and waves; representative tide and wave climates were used. At the open boundaries a so called morphological tide was described (Latteux 1995). Instead of multiple species of the semi-diurnal and diurnal-tide, only one diurnal- $\left(\mathrm{D}_{1}\right)$ and one semi-diurnal $\left(\mathrm{D}_{2}\right)$ component were taken into account. Similarly, the higher harmonics are also represented by only one component per frequency class. The amplitudes were 


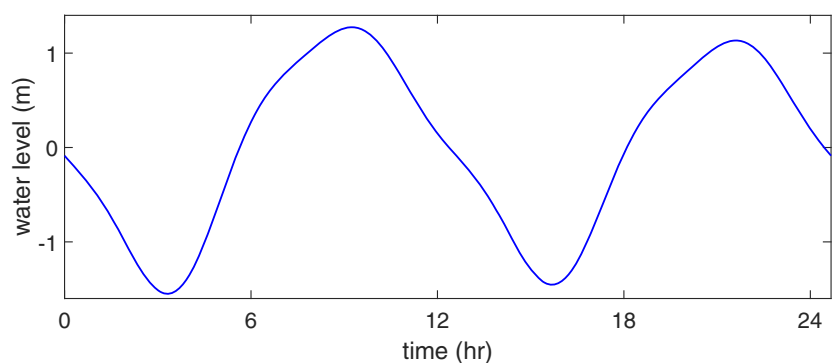

Fig. 3 Prescribed water levels at the Northern open boundary

chosen such that the morphological tide gives the same mean sediment transport over a spring-neap tidal cycle as when taking all harmonic components into account. The morphological tide consisting of seven constituents was derived by De Fockert (2008) by simulating two springneap cycles with the boundary conditions as extracted from the Extended Wadden Sea model (Deltares 2009). At the northern open boundary the morphological tide was forced by prescribed water levels (Fig. 3), while at the western and eastern open boundary Neumann conditions were prescribed (Roelvink and Walstra 2004). The value of the mean water level was related to the wave conditions as will be explained below.

The wave climate was represented by wave classes (Table 1), which were based on data collected by Rijkswaterstaat at the measuring station of Schiermonnikoog (Fig. 2). The analyzed dataset comprised 20 years (i.e., 1994 to 2014) of hourly measurements of the significant wave height $H_{s}$, mean wave direction $\theta$ and mean wave period $T_{m 02}$. Subsequently, the data were coupled to data of hourly measurements of water level at the measuring station Terschelling Noord (Fig. 2). The storm surge height (tidal mean water level) was estimated by subtracting the astronomical tide from the measured water level. By this, we had a data set of occurring wave conditions and related mean water level. The wave and mean water level data were smoothed using a running mean with a 6-h window in order to reduce impact of short-term fluctuations in wave height on the wave class determination. Subsequently, the data were binned based on wave direction ( $45^{\circ}$ increments) and sorted according to significant wave height. For each of the four offshore directions (west, northwest, north, northeast), the waves were binned in $0.5 \mathrm{~m}(1 \mathrm{~m})$ increments for $H_{s}<1 \mathrm{~m}\left(H_{s}>1 \mathrm{~m}\right)$. Wave classes accounting for less

Table 1 Definition of wave classes, corresponding boundary conditions and relative yearly occurrence

\begin{tabular}{|c|c|c|c|c|c|c|c|}
\hline Wave class & & Bin & $H_{s}$ & $T_{m 02}$ & $\theta$ & Mean water level & Occurrence $(\%)$ \\
\hline W0 & West & $0-0.5 \mathrm{~m}$ & $0.4 \mathrm{~m}$ & $3.43 \mathrm{~s}$ & $275.48^{\circ}$ & $0.06 \mathrm{~m}$ & 2.19 \\
\hline W0.5 & $247.5^{\circ}<\theta<292.5^{\circ}$ & $0.5-1 \mathrm{~m}$ & $0.76 \mathrm{~m}$ & $3.70 \mathrm{~s}$ & $271.77^{\circ}$ & $0.10 \mathrm{~m}$ & 7.87 \\
\hline W1 & & $1-2 m$ & $1.39 \mathrm{~m}$ & $4.37 \mathrm{~s}$ & $273.55^{\circ}$ & $0.22 \mathrm{~m}$ & 10.07 \\
\hline W2 & & $2-3 m$ & $2.36 \mathrm{~m}$ & $5.28 \mathrm{~s}$ & $278.96^{\circ}$ & $0.47 \mathrm{~m}$ & 1.77 \\
\hline W3 & & $3-6 m$ & $3.42 \mathrm{~m}$ & $6.15 \mathrm{~s}$ & $284.16^{\circ}$ & $0.75 \mathrm{~m}$ & 0.31 \\
\hline NW0 & Northwest & $0-0.5 \mathrm{~m}$ & $0.35 \mathrm{~m}$ & $4.10 \mathrm{~s}$ & $317.84^{\circ}$ & $0.02 \mathrm{~m}$ & 5 \\
\hline NW0.5 & $292.5^{\circ}<\theta<337.5^{\circ}$ & $0.5-1 \mathrm{~m}$ & $0.75 \mathrm{~m}$ & $4.51 \mathrm{~s}$ & $316.42^{\circ}$ & $0.02 \mathrm{~m}$ & 8.75 \\
\hline NW1 & & $1-2 \mathrm{~m}$ & $1.45 \mathrm{~m}$ & $5.04 \mathrm{~s}$ & $316.14^{\circ}$ & $0.08 \mathrm{~m}$ & 12.92 \\
\hline NW2 & & $2-3 m$ & $2.41 \mathrm{~m}$ & $5.76 \mathrm{~s}$ & $316.82^{\circ}$ & $0.24 \mathrm{~m}$ & 4.58 \\
\hline NW3 & & $3-4 m$ & $3.43 \mathrm{~m}$ & $6.63 \mathrm{~s}$ & $317.3^{\circ}$ & $0.44 \mathrm{~m}$ & 1.65 \\
\hline NW4 & & $4-5 \mathrm{~m}$ & $4.40 \mathrm{~m}$ & $7.37 \mathrm{~s}$ & $319.56^{\circ}$ & $0.64 \mathrm{~m}$ & 0.55 \\
\hline NW5 & & $5-8 m$ & $5.67 \mathrm{~m}$ & $8.35 \mathrm{~s}$ & $322.33^{\circ}$ & $0.97 \mathrm{~m}$ & 0.19 \\
\hline NO & North & $0-0.5 \mathrm{~m}$ & $0.35 \mathrm{~m}$ & $4.00 \mathrm{~s}$ & $357.25^{\circ}$ & $-0.04 \mathrm{~m}$ & 4.87 \\
\hline N0.5 & $337.5^{\circ}<\theta$ & $0.5-1 \mathrm{~m}$ & $0.74 \mathrm{~m}$ & $4.52 \mathrm{~s}$ & $356.12^{\circ}$ & $-0.07 \mathrm{~m}$ & 7.77 \\
\hline $\mathrm{N} 1$ & $\theta<22.5^{\circ}$ & $1-2 m$ & $1.40 \mathrm{~m}$ & $5.02 \mathrm{~s}$ & $353.51^{\circ}$ & $-0.09 \mathrm{~m}$ & 7.63 \\
\hline $\mathrm{N} 2$ & & $2-3 m$ & $2.39 \mathrm{~m}$ & $5.66 \mathrm{~s}$ & $351.25^{\circ}$ & $-0.05 \mathrm{~m}$ & 1.71 \\
\hline N3 & & $3-6 m$ & $3.60 \mathrm{~m}$ & $6.69 \mathrm{~s}$ & $349.69^{\circ}$ & $0.06 \mathrm{~m}$ & 0.41 \\
\hline NE0 & Northeast & $0-0.5 \mathrm{~m}$ & $0.38 \mathrm{~m}$ & $3.35 \mathrm{~s}$ & $42.66^{\circ}$ & $-0.06 \mathrm{~m}$ & 2.72 \\
\hline NE0.5 & $22.5^{\circ}<\theta<67.5^{\circ}$ & $0.5-1 \mathrm{~m}$ & $0.74 \mathrm{~m}$ & $3.73 \mathrm{~s}$ & $46.45^{\circ}$ & $-0.12 \mathrm{~m}$ & 5.18 \\
\hline NE1 & & $1-2 \mathrm{~m}$ & $1.37 \mathrm{~m}$ & $4.38 \mathrm{~s}$ & $47.17^{\circ}$ & $-0.25 \mathrm{~m}$ & 3.92 \\
\hline NE2 & & $2-4 m$ & $2.37 \mathrm{~m}$ & $5.34 \mathrm{~s}$ & $39.16^{\circ}$ & $-0.41 \mathrm{~m}$ & 0.54 \\
\hline
\end{tabular}

The wave classes were based on data collected by Rijkswaterstaat at the measuring station of Schiermonnikoog (Fig. 2). Bin refers to range in which the data was binned based on significant wave height $H_{s}$. Furthermore, $T_{m 02}$ and $\theta$ are mean wave period and direction, respectively 
than $0.5 \%$ of that wave direction were combined with the previous wave class.

Together the 21 wave cases account for $91 \%$ of the total realizations, with the remaining $9 \%$ falling outside of the binned area because they come from directions that were not taken into account. The results show that mean water level is largest for waves coming from the northwest, and increases for increasing wave height. Waves that come from the north or northeast are concurrent with set down (negative mean water level).

For reasons of feasibility, wind forcing was not included in the simulations. The implications of excluding the wind effects will be discussed in Section 4.

\subsubsection{Model simulations and model analysis}

The duration of a model run was $12 \mathrm{D}_{2}$ tidal cycles (of $12 \mathrm{~h}$ $20 \mathrm{~m}$ each), of which $10 \mathrm{D}_{2}$ tidal cycles were used as spinup for the model and the last 2 were used for analysis. Since a morphological tide has been used, the $2 \mathrm{D}_{2}$ tidal cycles result in tidal mean sediment transport patterns that are representative for the spring-neap cycle. All combinations of wave class and bathymetry were simulated. Weighted mean values of tidally averaged flow velocity and sediment transport were calculated as the sum of each individual value per wave class multiplied by the relative occurrence.

For each phase of the cyclic evolution, we analyzed the:

- tidally averaged sediment transport;

- tidally averaged flow (mean flow);

- tidally averaged sediment transport through crosssections

SedTrans $=\int_{s_{0}}^{s_{n}}\left\langle\mathbf{q}_{\mathbf{s}}\right\rangle \cdot \mathbf{n} d s$,

where $\left\langle\mathbf{q}_{\mathbf{s}}\right\rangle$ is the tidally averaged sediment transport vector, which can be either the value per wave class or the weighted mean of all wave classes. Furthermore, n is the normal vector of the transect and $s$ is the distance along the transect between $s_{0}$ and $s_{n}$;

- wave energy fluxes through cross-sections

WaveFlux $=\int_{s_{0}}^{s_{n}} E \mathbf{C}_{\mathbf{g}} \cdot \mathbf{n} d s$

where $E$ is the wave energy and $\mathbf{C}_{\mathbf{g}}$ is the group velocity vector;

- wave energy dissipation.

Details of the cross-section positions are given in Section 3.
Sensitivity simulations were performed to study the main driving processes:

- default simulations, with waves and surge;

- simulations without waves, only surge and tide forcing;

- tide-only simulations, neither surge nor waves;

- symmetric tide-only simulations with symmetric semidiurnal $\mathrm{D}_{2}$-tide, excluding diurnal tides and higher harmonics $\left(\mathrm{D}_{4}, \mathrm{D}_{6}, \ldots\right)$ in the boundary conditions.

\subsubsection{Model validation}

De Fockert (2008) verified the modeled water levels by conducting a harmonic analysis, in which the modeled tidal constituents were compared with the measured water level obtained from Terschelling Noord, Nes, and Holwerd stations (Fig. 2). For the offshore location (Terschelling North Sea), the maximum deviation in the modeled and measured amplitudes of the main constituents was less than $2 \%$ with only a small differences in relative phases (less than $9^{\circ}$ ). For the measurement location Nes, located inside the basin, the best results were obtained with the grid resolution used in this study. However, De Fockert (2008) found that the relative amplitudes of the higher harmonics were overestimated up to $30 \%$. The third measurement location (Holwerd) is located far inside the tidal basin and the predictability regarding water levels was also accurate in this point far inside the basin. In total the modeled tidal water levels agreed well to the measurements. The robustness of the results was tested for different tidal boundary conditions and will be discussed in Section 4.

Wave propagation over the ebb-tidal delta was validated by comparing the tidally averaged values of modeled and measured significant wave height based on data of the six wave buoys indicated in Fig. 2. For this, we used the 2011bathymetry because no wave data were available for other years. The measured data were averaged over a shifting 12.5-h window. For all wave classes, comparable measured conditions for mean water level and wave direction were found for validation. As can be seen in Fig. 4, the model compares well $\left(R^{2}>0.96\right.$, in which $R$ is the correlation coefficient) with the measurements for the wave buoys offshore and on the west part of the inlet and ebb-tidal delta. The largest deviations were found for the eastern wave buoys A22 and A32, located near the terminal lobe of the ebb-tidal delta and in the main inlet channel. However, these are also the wave buoys that have the largest standard deviations in the measured data. This probably occurs because of the complex propagation of individual waves over the ebb-tidal delta situated between these wave buoys and the predominant wave direction. Additionally, Van der 

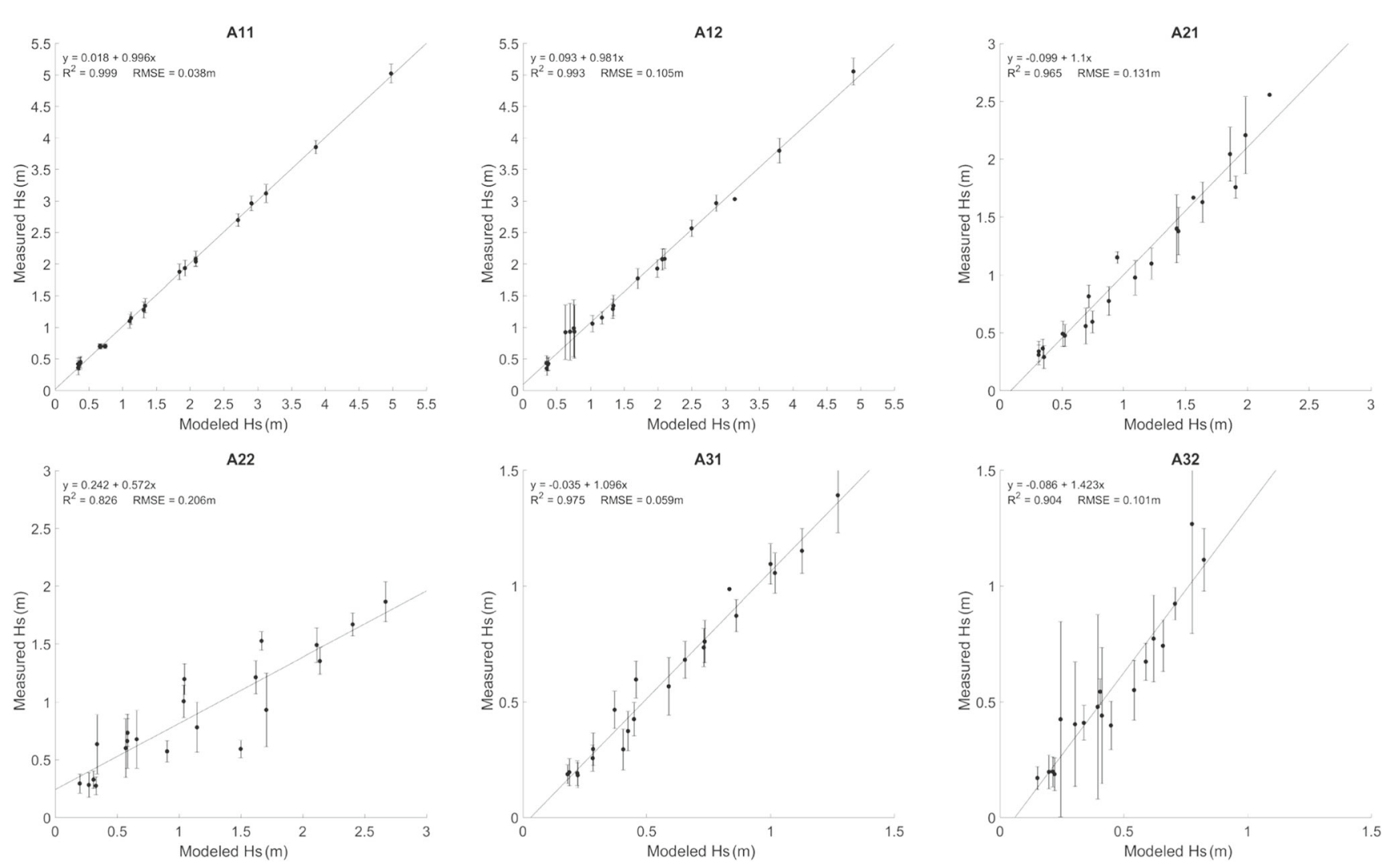

Fig. 4 Tidally averaged values of modeled and measured significant wave height for the six wave buoys indicated by black circles in Fig. 2. Every dot represents one wave class (Table 1) and the bars indicate the standard deviation of the measured data

Westhuysen (2012) also found good agreement between measured and modeled wave propagation inside the basin by comparing measured and model time series of wave data for the same system and model setup. Overall, the wave model performs satisfactory.

\section{Results}

\subsection{Wave energy patterns}

Figure 5 shows the weighted mean wave energy flux and energy dissipation rate, indicating that waves dissipate their energy as they propagate over the shallow ebb-tidal delta, which in turn protects Ameland and Terschelling islands and the back-barrier basin from incoming wave energy. Particularly Ameland is well protected as the ebb-tidal delta is situated between the island and the predominant wave direction. Protection of the west part of Ameland is most evident during phase 1, i.e., when the shoal is close to the island coast. After the shoal attachment, wave energy can propagate further landward and more energy is dissipated near the shore (phases 2 and 3). The presence of a new shoal on the ebb-tidal delta causes the patterns during phase 4 to resemble those of phase 1, with energy dissipation over the shoal and less dissipation near the shore. However, as the shoal position differs, so does the area of increased wave energy dissipation.

Compared to Ameland, the east part of Terschelling is less well protected from the incoming wave energy flux as illustrated by the relatively high dissipation rates in the nearshore zone during all phases of the cyclic evolution. This exposure is mainly related to the mean wave direction and absence of protection against the northwestern waves by the ebb-tidal delta.

Wave energy dissipation by the various parts of the ebbtidal delta was quantified using three series of $2500 \mathrm{~m}$ cross-sections perpendicular to the lines oriented to the northwest (S1) and to the north (S2) of Ameland and to the northwest of Terschelling (S3), respectively. The S1- and S2-line intersect with the northwesternmost and northernmost point of the Ameland coast. Similarly, the 

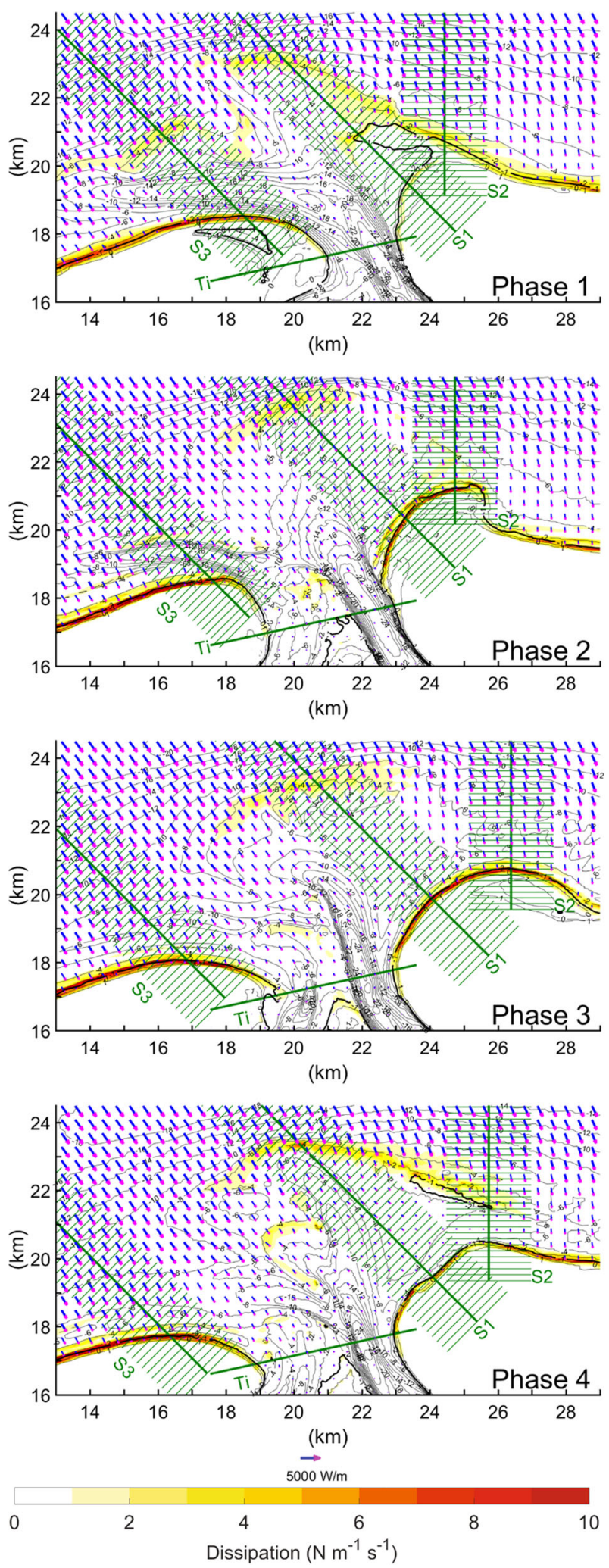

Fig. 5 Vector plot of the weighted mean wave energy flux during the four phases of the cyclic behavior. The arrows are interpolated to a rectilinear grid. Colors indicate wave energy dissipation. Cross-section $\mathrm{Ti}$ and the series of cross-sections $\mathrm{S} 1, \mathrm{~S} 2$, and $\mathrm{S} 3$ are shown in green. Black lines represent the bathymetry in intervals of $2 \mathrm{~m}$ with thick line at $1 \mathrm{~m}$ isobath
S3-line intersects with the northernmost grid cell of Terschelling. As the bathymetry varies per phase, so do the locations of S1, S2, and S3. In the sensitivity analysis, these locations were fixed; this did not cause qualitative differences in outcome.

The wave energy flux through the cross-sections relative to the most seaward cross-section is shown in Fig. 6. The cross-sections S1 (facing the northwest of Ameland) show that the island is most effectively protected from offshore wave energy by the shoal on the ebb-tidal delta. During the phases with a shoal close to the coast (phases 1 and 4), less than $18 \%$ of the incoming wave energy dissipates within $500 \mathrm{~m}$ of the coast, whereas during the other phases this is more than twice as much. Not surprisingly, the lowest values of remaining wave energy for S2 occur when the shoal is located more towards the north of Ameland. The cross-sections S3 indicate that the fraction of wave energy dissipation within $1000 \mathrm{~m}$ of the coast of Terschelling almost doubled during phases $3(54 \%)$ and $4(55 \%)$ and that less energy is dissipated offshore compared to phase 1 . This trend seems to be related to the disappearance of the Westgat and its related ebb-shield north of Terschelling.

We also analyzed the weighted mean energy flux through a cross-section Ti in the inlet (Fig. 6). The total amount of wave energy that enters the basin increases as the inlet transforms from a one-channel (phase 1) to a two-channel system (maximum during phase 3 ). This trend can only partially be explained by the increasing width of the inlet. As can be seen from the similar increase in maximum values (Fig. 6), these variations are caused by the wave filtering on the ebb-tidal delta. It is worthwhile to note that the differences in wave energy through the inlet resemble those close to Terschelling; also, the increase in wave energy is mostly in the part of the inlet closest to Terschelling. This similarity suggests that most protection from incoming wave energy is provided by the west part of the ebb-tidal delta and the Westgat.

This analysis indicates that the cyclic evolution of the ebb-tidal delta has a significant impact on wave energy in the Ameland basin, and on the wave energy reaching the nearshore zone of Ameland and Terschelling. It is expected that this also impacts the sediment transport patterns on the ebb-tidal delta and in the inlet.

\subsection{Sediment transport}

We focused on the four key regions indicated in Fig. 1, namely, (1) the terminal lobe; (2) the downdrift coast; (3) the updrift coast; and (4) the tidal inlet. For these regions, we show the patterns and magnitudes of weighted mean, tidally averaged, total (bed load + suspended load) sediment transport, hereafter referred to as weighted mean or net sediment transport. 

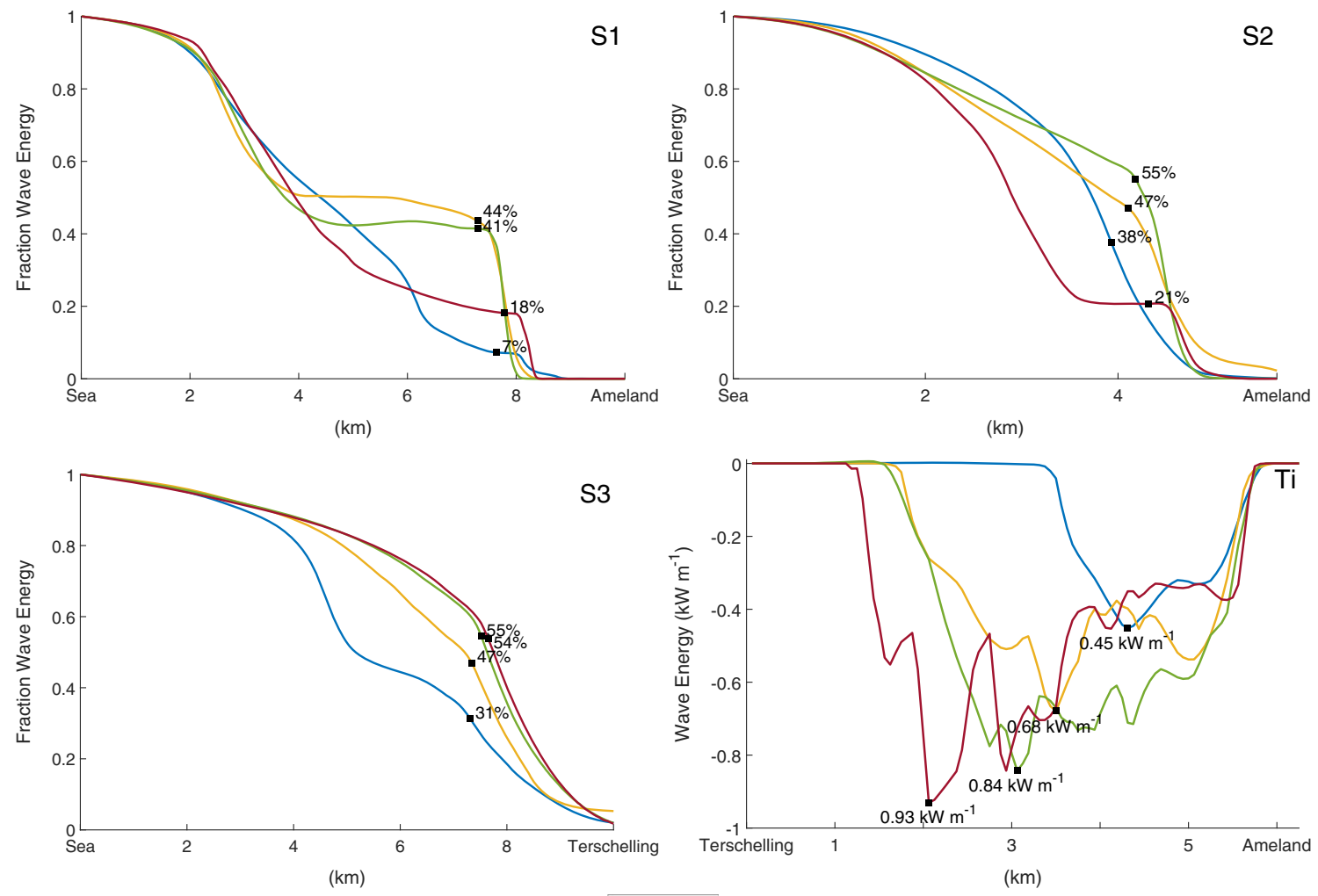

-Phase 1

-Phase 2

-Phase 3

-Phase 4

Fig. 6 Fraction of remaining weighted mean wave energy flux through the series of cross-sections S1, S2, and S3 and weighted mean wave energy flux through cross-section Ti. The locations of the crosssections are shown in Fig. 5. The different line colors correspond to

\subsubsection{Terminal lobe}

As shown in Fig. 7, the direction of weighted mean sediment transport features a transition from seaward at the end of the ebb-dominant main channel/ebb-shield to downdrift further seaward. The latter transport represents the sediment bypassing of the ebb-tidal delta. Among the phases the patterns are roughly the same, following the rotation of the main ebb-channel; only sediment transport magnitudes differ. To quantify the sediment bypassing, a series of $1 \mathrm{~km}$ long cross-sections were defined (S4) perpendicular to the terminal lobe; the net sediment transports through these are presented in Fig. 9a. The location of S4 was based on the $7 \mathrm{~m}$ isobath line and has a fixed east-west location (range of $4 \mathrm{~km}$ ). Only for phase $1, \mathrm{~S} 4$ was shifted slightly to the west because the Akkepollegat had a more updrift orientation.

As can be seen, the sediment bypassing decreases as the orientation of the Akkepollegat changes from northwest during phase 1 to north during phase 4. It was tested whether this reduction resulted from the variations in wave characteristics or from changes in tidal currents. The dashed different phases. The percentages of remaining weighted mean wave energy flux for are taken $500 \mathrm{~m}$ (S1 and S2) or $1000 \mathrm{~m}$ (S3) off the coast, respectively. The values shown for Ti are the maximum value per phase

lines in Fig. 9a show the outcome of the simulations without waves. Excluding the waves diminishes the bypassing magnitude, but does not have significant influence on the fluctuations over the phases. Based on this, it was concluded that the decrease in sediment bypassing originates from tidal changes forced by rotation of the ebb-channel. More specifically, the channel displacement changes mean flow along the terminal lobe with a maximum value during phase 2 of $0.17 \mathrm{~m} / \mathrm{s}$ and minimum value during phase 4 of $0.11 \mathrm{~m} / \mathrm{s}$.

Another notable result of both default simulations and simulations without waves is that bypassing during phase 1 was relatively strong in the west of the ebb-tidal delta and relatively weak in the east. This spatial variability also results from the tide-driven transport, possibly because during phase 1 the Westgat was the dominant channel.

\subsubsection{Downdrift coast: Ameland}

The weighted mean sediment transport along the northwestern coast of Ameland shows a diverging pattern during all 

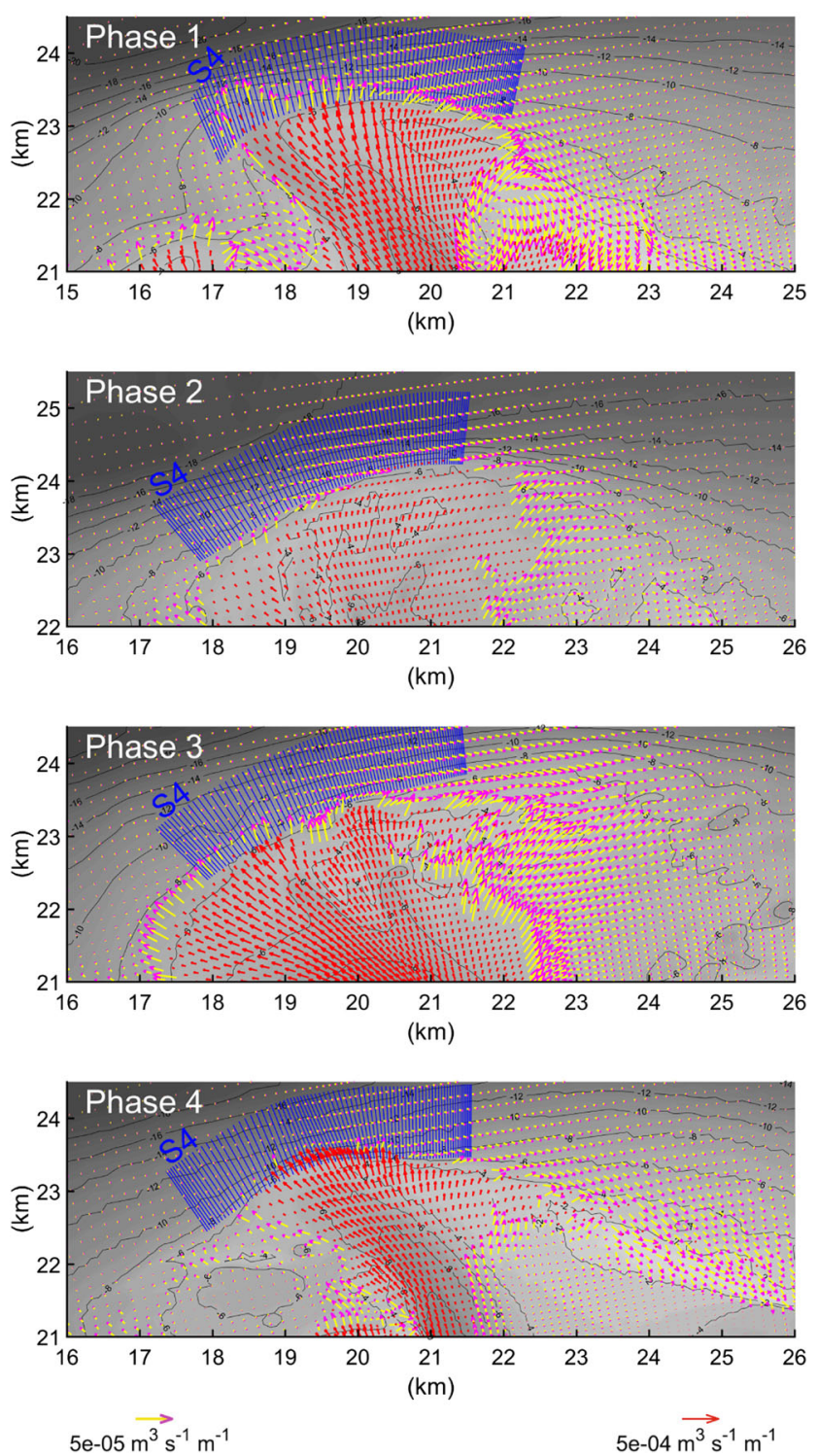

Fig. 7 Vector plot of the weighted mean sediment transport for the terminal lobe of the ebb-tidal delta. The arrows are shown in every second grid cell in both directions. The yellow/magenta vectors are a factor ten shorter than the red vectors for the same vector length. The blue lines indicate the series of cross-sections perpendicular to the terminal lobe (S4). Black lines represent the bathymetry in intervals of $2 \mathrm{~m}$

phases as its direction is towards the tidal inlet in the west and downdrift more in the east (Fig. 8). Visual comparison of the four phases reveals differences in sediment transport towards the inlet; for example, transport of sediment was most intensive during phase 3 . Interestingly, the net sediment transport during phase 4 south of the new shoal appears to be small with significant downdrift net transport on and directly seaward of the new shoal. The prominent role of the shoal (offshore blue line) in the patterns
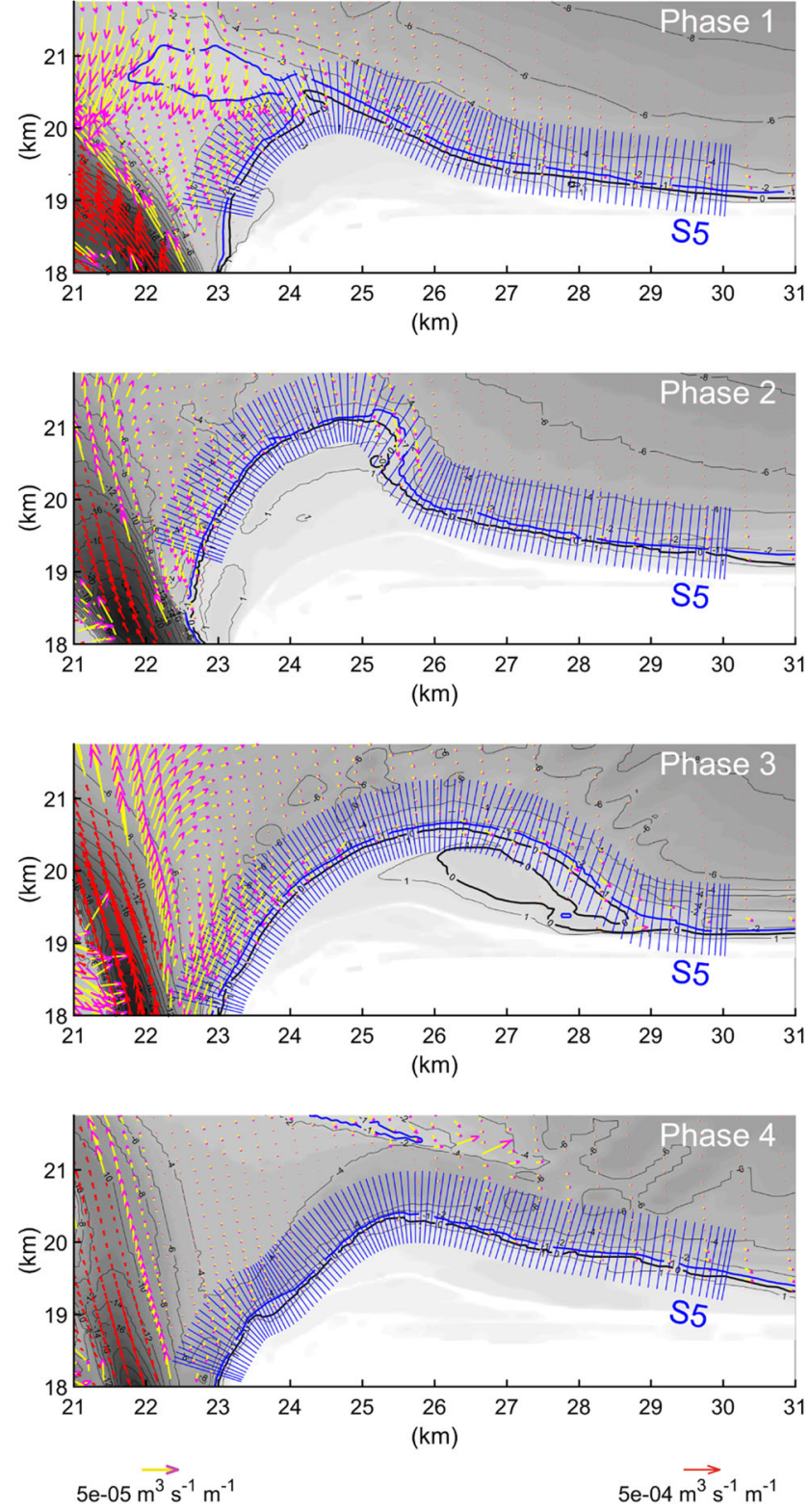

Fig. 8 Vector plot of the weighted mean sediment transport for the northwest part of Ameland. The arrows are shown in every fourth grid cell in both directions. The yellow/magenta vectors are a factor ten shorter than the red vectors for the same vector length. The thin blue lines indicate the series of cross-sections perpendicular to the coast (S5). Black lines represent the bathymetry in intervals of $2 \mathrm{~m}$ with blue contour at $1 \mathrm{~m}$ isobath

of weighted mean sediment transport is also clear during phase 1 as the convergence of the sediment transport vectors indicates that the ebb-tidal delta was in the phase of shoal migration.

Sediment transport along the coast was calculated for $1 \mathrm{~km}$ long cross-sections perpendicular to the coast (S5). Each cross-section of S5 intersects with the northernmost $0 \mathrm{~m}$ isobath at a predefined east-west location (range 

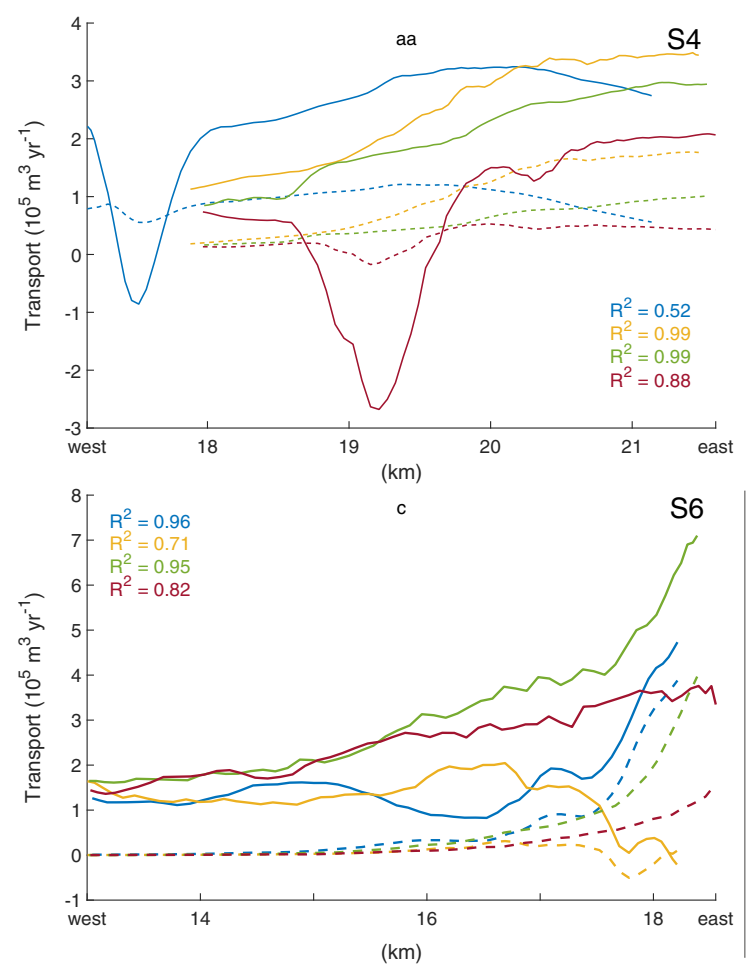

Fig. 9 Weighted mean sediment transport through the series of crosssections S4 (a), S5 (b), and S6 (c) shown in Figs. 7, 8, and 10, respectively. The average east-west location of each cross-section is

of $7 \mathrm{~km}$ ). As shown in Fig. 9b, the magnitude of the sediment transport through the westernmost cross-section is directed towards the tidal inlet (negative) and depends on the phase of the cyclic shoal dynamics with increasing sediment transport while the shoal forms (phase 4), migrates (phase 1), attaches (phase 2) and spreads out over the coast (phase 3). This dependency suggests a major role of changes in the wave filtering effect of the ebb-tidal delta. Therefore, default simulations (solid lines) and simulations without waves (dashed) were compared. This indicates that the sediment transport is indeed strongly related to the amount of wave energy in the nearshore zone. However, it is the relatively strong tide driven transport during phase 1 that explains why net sediment transport at certain cross-sections is relatively high.

\subsubsection{Updrift coast: Terschelling}

As shown in Fig. 10, the weighted mean sediment transport near Terschelling is directed towards the inlet and represents the littoral drift. Variations in magnitude can be seen, both spatially and among the phases. During all phases the transport increases in the downdrift direction and reaches its maximum near the inlet. However, it can also be seen

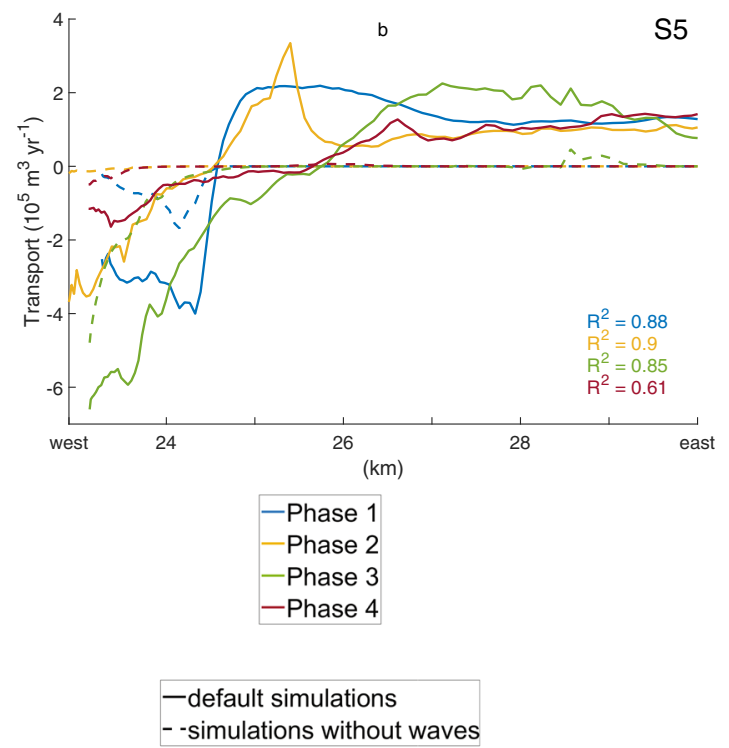

used. Solid: default model simulations; dashed: model simulations without wave forcing. Positive values are in the downdrift (eastward) direction. The $R^{2}$ between the solid and dashed lines is given per phase

that the littoral drift during phases 3 and 4 is larger than during the first two phases. Further offshore in the Westgat, net sediment transport is in the opposite direction. This transport is largest during phase 1 when this channel is deepest and directly connected to the deep channel in the inlet. During the other phases sediment transports through the Westgat is smaller as the channel is more filled up.

This spatial and temporal variability in alongshore sediment transport was quantified with $1 \mathrm{~km}$ long crosssections perpendicular to the coast (S6, range of $5 \mathrm{~km}$, defined using the same method as S5). As shown in Fig. 9c, the alongshore sediment transport during phases 3 and 4 exceed that during phases 1 and 2. Comparison with the simulations without waves (dashed lines) reveals that this variability is wave-related. The ebb-shield related to the presence of the Westgat is smaller during phases 3 and 4 (Section 3.1), thereby making the coast of Terschelling less protected. Closer to the inlet, however, it is the tide-driven transport that causes higher values during phases 1 and 4 .

The above analysis shows that the contraction of the Westgat has a significant impact on transport in sediment transport along Terschelling. As the formation of a new ebbchannel in northwestern direction is part of phase 4 , the outcome can be seen as part of a cycle rather than a trend. 

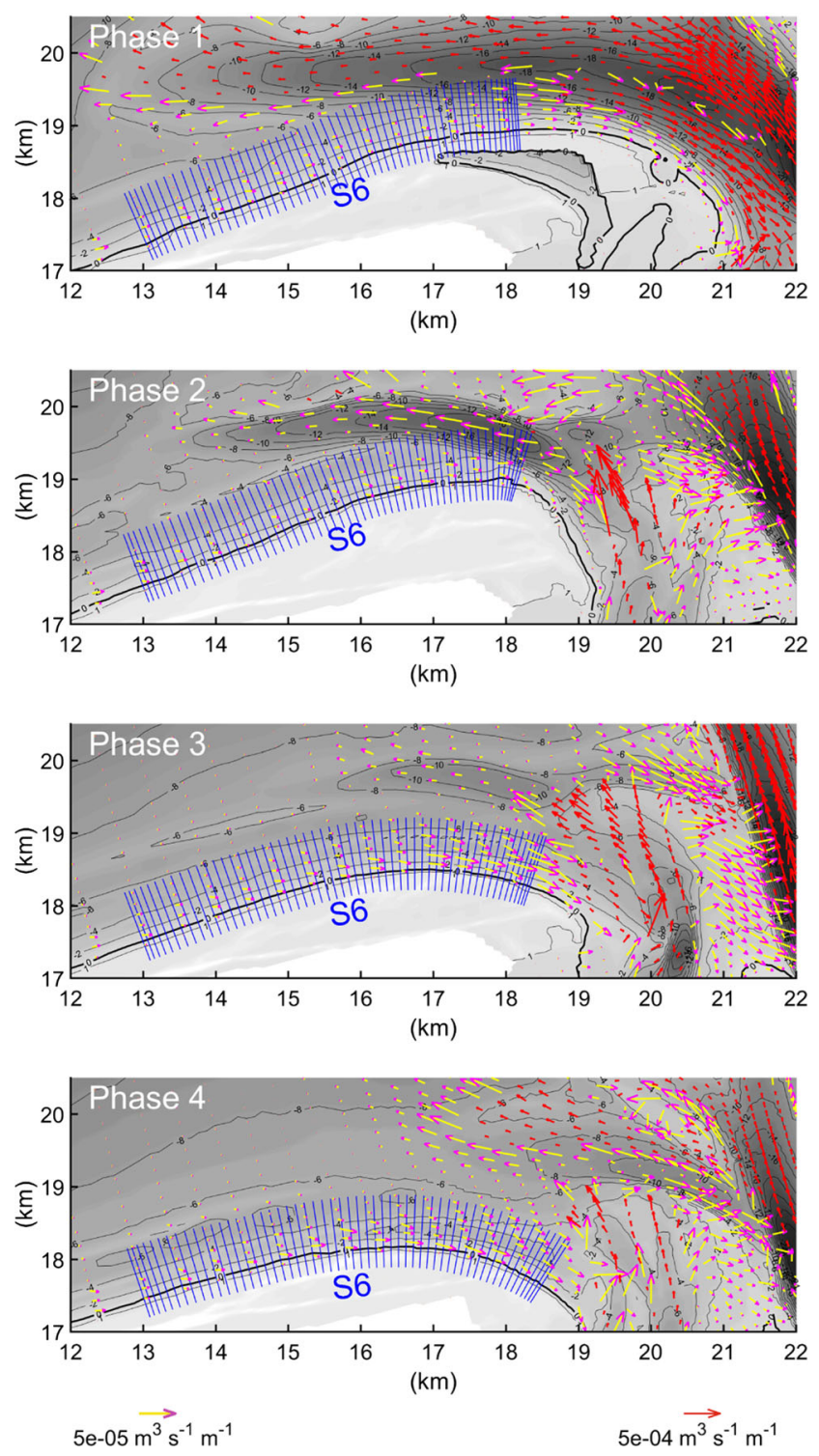

Fig. 10 Vector plot of the weighted mean sediment transport for the northeast part of Terschelling. The arrows are shown in every fourth grid cell in both directions. The yellow/magenta vectors are a factor ten shorter than the red vectors for the same vector length. The blue lines indicate the series of cross-sections perpendicular to coast (S6). Black lines represent the bathymetry in intervals of $2 \mathrm{~m}$

\subsubsection{Tidal inlet}

As shown in Fig. 11, the net sediment transport patterns in the inlet vary significantly among the phases. Net sediment transport is seaward in the eastern part when the inlet has a one-channel configuration during phase 1 . However, the relatively large tide-driven sediment transport along Terschelling cause a net transport into the basin in the western part of the channel. During phases 2, 3, and 4, both
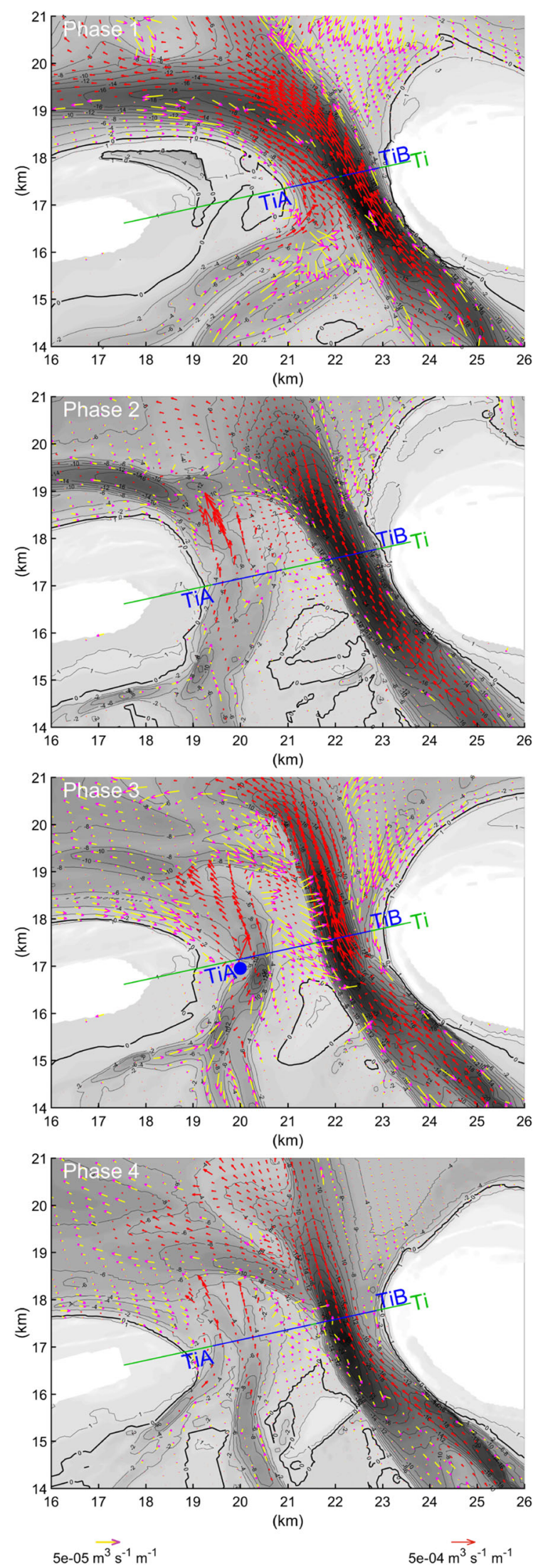
4Fig. 11 Vector plot of the weighted mean sediment transport near the inlet. The arrows are shown in every fourth grid cell in both directions. The yellow/magenta vectors are a factor ten shorter than the red vectors for the same vector length. Cross-section $\mathrm{Ti}$ is shown in green and cross-sections TiA and TiB in blue. The blue dot in phase 3 indicates the shallow part of the secondary channel. Black lines represent the bathymetry in intervals of $2 \mathrm{~m}$

channels transport sediment from basin to sea. This export via both channels appears to be largest when the western channel is deepest (phase 3 ).

The net exchange between basin and sea was calculated for a cross-section across the Ameland inlet. Cross-section Ti covers the entire inlet (as in Section 3.1); cross-section TiA and TiB represent the western and eastern part of the inlet deeper than $2.5 \mathrm{~m}$, respectively. The net sediment transport through the cross-sections is listed in Table 2. The results show that the net exchange is cyclic and follows the periodicity of the one- and two-channel inlet configurations. Net export is largest when the western channel reaches its maximum size (phase 3) and smallest when the inlet features one channel (phase 1). Cross-sections TiA and TiB show that a cyclic evolution of export is present for both channels. Interestingly, net export in the east (TiB) during phase 1 exceeds total net export of phases 2 and 4 ; however, this is compensated by import in the west (TiA).

Sensitivity experiments were analyzed to determine why the export through the tidal inlet is highly variable. First, it was tested whether waves in the inlet were the main factor by comparing default simulations and simulations without waves. During all four phases, excluding the waves had the same effect of an increase of the export of less than $10^{6} \mathrm{~m}^{3} /$ year. This indicates that the large variability in export is not related to the change in wave intensity and is thus caused by tidal dynamics.

Secondly, tide-only simulations (no waves and no surge) were analyzed to study the role of changes in the mean flow and changes in the tidal asymmetry. These mechanisms were quantified using harmonic analysis for the two locations in the inlet with the highest net transport in the two channels. As shown in Table 3, $U_{e b b}, U_{f l o o d}, C_{e b b}$,

Table 2 Weighted mean net sediment transport in $10^{6} \mathrm{~m}^{3} /$ year through the cross-sections in the inlet

\begin{tabular}{lllll}
\hline Cross-section & Phase 1 & Phase 2 & Phase 3 & Phase 4 \\
\hline Ti & 0.79 & 3.84 & 14.86 & 6.11 \\
TiA & -5.93 & 0.82 & 5.90 & 2.31 \\
TiB & 6.81 & 2.97 & 7.71 & 2.84 \\
\hline
\end{tabular}

Positive values are in the seaward direction (export) and $C_{\text {flood }}$ are the maximum along-channel flow velocities $U$ and sediment concentrations $C$ during ebb and flood. Furthermore, $A_{0}, A_{2}$, and $A_{4}$ are the amplitudes of mean, semi- and quarter-diurnal flow with phases $\phi_{2}$ and $\phi_{4}$. Note that the effects of mean flow and tidal asymmetry on net sediment transport are in the direction of the sign of $A_{0}$ and $\cos \left(2 \phi_{2}-\phi_{4}\right)$, respectively. In the latter, $2 \phi_{2}-\phi_{4}$ is the relative phase difference between the semi- and quarterdiurnal flow. In the eastern channel, which is the main channel in all phases, the maximum ebb flow exceeds the maximum landward flood flow. In the western channel, the peak flow is in the flood direction during phase 1 and in the ebb direction in the other phases. For the one-channel configuration (phase 1), it is the relatively strong mean flow that causes larger flow velocities during ebb in the east and during flood in the west. When the bathymetry features a small secondary channel (phases 2 and 4), larger $A_{4}$ and smaller $A_{0}$ values are found in the main eastern channel, with the relative phase difference indicating ebbdominance; here, export appears to be a combined effect of mean flow and tidal asymmetry. In the western channel, export is limited because of limited water depth. With a fully developed second channel (phase 3 ), the moderate $A_{0}$ values and low $A_{4}$ values minimizes the difference between maximum ebb and flood flow. However, export reaches maximum values because of strong semi-diurnal flow in the eastern channel and high sediment concentrations in the western channel. These are caused by ebb flow accelerating over the shallow part of this channel (indicated by the blue dot in Fig. 11).

Subsequently, it was tested whether these differences result from internal or external asymmetry by analyzing symmetric tide-only simulations (no $\mathrm{D}_{1}, \mathrm{D}_{4}, \mathrm{D}_{6}, \ldots$ ). Comparing the outcome for cross-section TiB in Table 4 with Table 3 reveals an increase in $A_{4}$ and $2 \phi_{2}-\phi_{4}$. This indicates that the internally generated overtides induce ebbdominance. Since the externally forced tidal asymmetry is flood-dominant, the difference between maximum ebb and flood flow velocities is larger for symmetric forcing than in the tide-only simulations with external asymmetric tide. The values indicate that more tidal asymmetry is generated internally during the phases where tidal asymmetry was found to be an important exporting mechanism (phases 2 and 4). As expected, the mean flow is not significantly affected.

Lastly, it was examined how the tides in the inlet are affected by the storm surge height (mean water level). Figure 12 shows the tidal characteristics for simulations without waves. Two main effects of increasing mean water level can be seen, namely, (1) the value of mean flow increases; and (2), ebb-dominance changes to flooddominance as indicated the relative phase difference. This 
Table 3 Maximum alongchannel tidal flow and sediment concentration in the inlet at the locations of maximum net sediment transport in cross-section TiA and TiB

\begin{tabular}{lllll}
\hline Western channel (cross-section TiA) & Phase 1 & Phase 2 & Phase 3 & Phase 4 \\
\hline$U_{\text {ebb }}(\mathrm{m} / \mathrm{s})$ & 1.33 & 1.67 & 1.56 & 1.45 \\
$C_{\text {ebb }}\left(10^{-5} \mathrm{~m}^{3} / \mathrm{m}^{3}\right)$ & 7.88 & 16.4 & 37.53 & 11.58 \\
$U_{\text {flood }}(\mathrm{m} / \mathrm{s})$ & -1.69 & -1.26 & -1.37 & -0.97 \\
$C_{\text {flood }}\left(10^{-5} \mathrm{~m}^{3} / \mathrm{m}^{3}\right)$ & 12.67 & 7.16 & 5.08 & 1.96 \\
$A_{0}(\mathrm{~m} / \mathrm{s})$ & -0.36 & 0.16 & 0.04 & 0.18 \\
$A_{2}(\mathrm{~m} / \mathrm{s})$ & 1.23 & 1.45 & 1.47 & 1.23 \\
$A_{4}(\mathrm{~m} / \mathrm{s})$ & 0.28 & 0.07 & 0.07 & 0.05 \\
$2 \phi_{2}-\phi_{4}\left({ }^{\circ}\right)$ & 123 & 78 & 92 & 2 \\
Eastern channel (cross-section TiB) & & & & \\
$U_{\text {ebb }}(\mathrm{m} / \mathrm{s})$ & 1.94 & 1.74 & 1.92 & 1.68 \\
$C_{\text {ebb }}\left(10^{-5} \mathrm{~m}^{3} / \mathrm{m}^{3}\right)$ & 9.47 & 5.47 & 13.45 & 5.79 \\
$U_{\text {flood }}(\mathrm{m} / \mathrm{s})$ & -1.29 & -1.22 & -1.65 & -1.25 \\
$C_{\text {flood }}\left(10^{-5} \mathrm{~m}^{3} / \mathrm{m}^{3}\right)$ & 1.60 & 1.06 & 3.07 & 1.11 \\
$A_{0}(\mathrm{~m} / \mathrm{s})$ & 0.23 & 0.06 & 0.10 & 0.08 \\
$A_{2}(\mathrm{~m} / \mathrm{s})$ & 1.66 & 1.46 & 1.82 & 1.48 \\
$A_{4}(\mathrm{~m} / \mathrm{s})$ & 0.07 & 0.18 & 0.05 & 0.14 \\
$2 \phi_{2}-\phi_{4}\left({ }^{\circ}\right)$ & 26 & 32 & 26 & 20 \\
\hline
\end{tabular}

Positive flow velocity values are in the seaward (ebb) direction transition coincides with minimum values of the quarterdiurnal flow velocities and are caused by intertidal flats. For low mean water level values, the flats are flooded only at high water and cause ebb-dominance. However, at high mean water level, the flats are inundated during a larger part of the tidal cycle and since inundated flats enhance the effect of friction, they cause flood-dominance. Additionally, non-linear effects become less important; thus, weaker overtides are generated internally and make the external asymmetry dominant. Since more ebb-asymmetry is generated internally during phases 2 and 4 , the transition to flood-dominance occurs for larger values of mean water level.

Table 4 Tidal flow characteristics at the location of maximum net sediment transport in cross-section $\mathrm{TiB}$ for tide-only simulations with symmetric tides (no external tidal asymmetry)

\begin{tabular}{lllll}
\hline Symmetric tidal forcing & Phase 1 & Phase 2 & Phase 3 & Phase 4 \\
\hline$U_{\text {ebb }}(\mathrm{m} / \mathrm{s})$ & 2.01 & 1.76 & 2.07 & 1.73 \\
$U_{\text {flood }}(\mathrm{m} / \mathrm{s})$ & -1.25 & -1.22 & -1.57 & -1.18 \\
$A_{0}(\mathrm{~m} / \mathrm{s})$ & 0.22 & 0.06 & 0.11 & 0.08 \\
$A_{2}(\mathrm{~m} / \mathrm{s})$ & 1.65 & 1.40 & 1.83 & 1.43 \\
$A_{4}(\mathrm{~m} / \mathrm{s})$ & 0.25 & 0.37 & 0.26 & 0.32 \\
$2 \phi_{2}-\phi_{4}\left(^{\circ}\right)$ & 43 & 49 & 50 & 41
\end{tabular}

Positive flow values are in the seaward/ebb direction

\section{Discussion}

The paper first addressed the effect of changing ebb-tidal delta morphology on patterns of wave energy fluxes and wave energy dissipation rates. Figures 5 and 6 show that it is the position of the shoal that determines the wave energy fluxes towards the coast of the downdrift island and thus the nearshore wave energy dissipation. However, the wave energy entering the basin and the nearshore zone of the updrift island depends mostly on the size of the updrift channel. The modeled response of wave energy to morphodynamic changes is consistent with Hansen et al. (2013), who reported that the retreating ebb-tidal delta of San Francisco Bay increased the exposure of the adjacent beach to wave energy, particularly during energetic conditions.

Many studies on sediment transport near tidal inlet systems have neglected the effect of waves (Van Leeuwen et al. 2003; Van der Vegt et al. 2006, 2009; Dissanayake et al. 2012). However, as shown in Fig. 9, the sediment transport patterns were directly influenced by the changes in wave propagation. Not surprisingly, transport along the coasts of the barrier islands is higher during the phases with more wave energy dissipation close to the coast. Consequently, these transports increased with increasing wave energy (not shown). This increase agrees with the findings of Herrling and Winter (2014) who found waveinduced along-shore currents that transport the entrained 

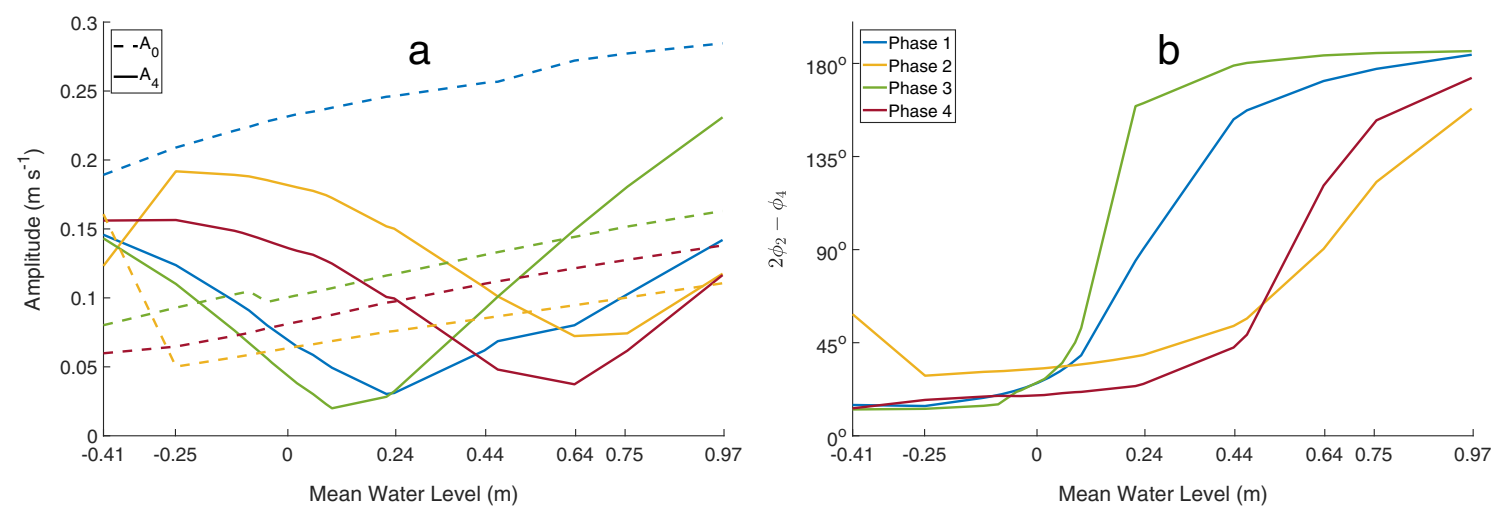

Fig. 12 Amplitude of mean flow (a, dashed line), quarter-diurnal flow (a, solid line) and the relative phase difference (b) in the inlet as a function of mean water level

sand towards the inlet. Although every ebb-tidal delta is unique, many have similar cyclic behavior (FitzGerald et al. 2000; Ridderinkhof et al. 2016). It is expected that these tidal inlets will share the periodic variations in wave energy near the barrier islands and into the basin. As shown, this causes cyclic changes in littoral drift along the updrift island and sediment transport along the downdrift island.

Herrling and Winter (2014) also showed that sediment bypassing along the terminal lobe is mostly wave-driven, which is confirmed in the present study. However, we show that the variations in wave patterns in this area did not significantly affect the fluctuations of the modeled sediment bypassing along the terminal lobe. In fact, the magnitude of the downdrift-oriented tidal mean flow along the terminal lobe decreases when the ebb-channel rotates eastward. As many ebb-tidal deltas have migrating channels (FitzGerald et al. 2000), they are expected to have cyclic sediment bypassing.

In the inlet, the morphological changes have altered the tidal characteristics. The relative differences in tidal flow among the phases do not depend on the boundary conditions. For all tested sets of boundary conditions, the following three effects were found: (1) the mean flow in the inlet is especially strong for a one-channel configuration and weak for a two-channel configuration; (2) the tidal signal is deformed most by a shallow secondary channel; and (3) semi-diurnal flow in the inlet is strongest with a fully-developed secondary channel. The periodic shifting between one and two channels is observed at many tidal inlets (Cayocca 2001; Kleinhans et al. 2015; Ridderinkhof et al. 2016). These findings indicate that cyclic variations in tidal asymmetry, mean flow, and flow magnitudes are an inherent feature of the cyclic inlet configuration.

These temporal variations in tidal characteristics result in distinct patterns of net sediment transport in the inlet. The exchange of sediment between basin and sea has only been studied as a function of basin geometry (Speer and
Aubrey 1985; Friedrichs and Aubrey 1988; Ridderinkhof et al. 2014a, b) and the effects of ebb-tidal deltas has been ignored. However, the present study has shown that the cyclic behavior of ebb-tidal deltas affects the net sediment transport in the inlet. The largest value for export was found for a two-channel configuration in spite of a relatively weak tidal asymmetry and mean flows. In contrast, the strong mean flows that characterize the one-channel inlet result in a balance of import in the west and export in the east. Furthermore, the relatively distorted signal during the transitional phases in inlet configuration forces moderate export values. This suggests that the net exchange between basin and sea at this type of tidal inlets is cyclic and follows the periodicity of the one- and two-channel inlet configurations.

In this study, Ameland was used as a case study for the effect of cyclic ebb-tidal deltas on patterns of waves, tides and sediment transport. However, this study did not aim to accurately simulate or estimate the sediment budget of Ameland inlet. Only the most relevant processes were modeled and the effects of wind, multiple grain sizes and connectivity with other basins were not taken into account. This simplified model setup had the effect of causing two noticeable discrepancies between measurements and model outcome.

Firstly, the model may have overestimated the export of sediment. As shown by Elias et al. (2012), both the ebbtidal delta and the back-barrier basin were governed by volume gain (respectively 33.7 and $56 \mathrm{Mm}^{3}$ ) between 1935 and 1995. They proposed that sediments in the basin were supplied by the adjacent Vlie inlet, since accretion primarily occurred near this watershed. However, they also observed that subsequently (1995-2005) the ebb-tidal delta had lost $6.1 \mathrm{Mm}^{3}$. Figure 11 shows that the model predicts transport of sand towards the ebb-tidal delta. This discrepancy can be attributed to (1) the use of a single grain size of $250 \mu \mathrm{m}$ and (2) the tidal boundary conditions (De Fockert 2008; Jiao 2014). 
The observed transition from export to import can partly be explained by relative sea level rise. Dissanayake et al. (2012) modeled the long-term development of realistic analogue of Ameland inlet system for various scenarios of relative sea level rise, which were found to correlate with an increase of flood-dominance. This is in line with our finding that the tidal asymmetry depends on the mean water level for all the modeled phases. Rising the mean water level decreases the internally generated ebb-dominance. As a result, the tidal asymmetry is largely determined by the externally generated asymmetry with the basin length the key factor in import and export (Ridderinkhof et al. 2014a, b).

Secondly, the model may have underestimated the littoral drift and sediment bypassing. It reproduces the littoral drift along the coasts of Terschelling and Ameland, but with magnitudes five times lower than previous estimates based on offshore wave climate (Cheung et al. 2007; Ridderinkhof et al. 2016). A possible explanation is that the effects of wind are not accounted for in this study. Since the winds come predominantly from the west, wind-driven and wavedriven flows are mostly in the same direction. Therefore, excluding the wind effects may have led to an appreciable underestimation of the along-shore sediment transport. Similarly, the modeled bypassing magnitude would increase if the effects of wind were taken into account; however, no estimates of sediment bypassing along the terminal lobe of the Ameland ebb-tidal delta are available.

The question of what the effects of (1) wind, (2) multiple grain sizes, (3) morphological updates and (4) connectivity with other basins would must be answered by future studies. Ongoing research aims to elucidate these physical processes.

\section{Conclusions}

This study identifies the impact of channel rotation, switching between a one- and two-channel inlet system and periodic development of a large sandy shoal on waves, tides, and sediment transport. Using Delft3D/SWAN, we have shown that many of the physical processes that characterize a tidal inlet system and an ebb-tidal delta are affected by the cyclic behavior of channels and shoals.

The along-shore sediment transport strongly relates to the amount of wave energy in the nearshore zone, whereas sediment transport through the inlet largely links with changes in tidal asymmetry and mean flow. The largest value for export was found for a two-channel inlet, the smallest for a one-channel inlet. Additionally, an updrift orientated main ebb-channel forces a mean flow that enhances the wave-driven sediment bypassing along the terminal lobe more than a symmetric channel.
A strong mean flow of up to $0.36 \mathrm{~m} / \mathrm{s}$ was found in a one-channel inlet which is more than two times higher than in a two-channel inlet. The overtides that were generated internally counteract the flood-dominant tidal currents generated externally. The ratio of the amplitudes of the quarter- and semi-diurnal tides is largest when the inlet features a not-fully-developed second channel. In contrast, the tidal signal is least deformed when the inlet consists of one channel or when the second channel has reached its maximum size.

A shallow shoal on the ebb-tidal delta enhances the offshore wave energy dissipation, thereby protecting the downdrift coast from incoming wave energy. Similarly, the updrift island and the inlet are best protected by the banks of the updrift channel, which is deepest when the inlet features one channel.

Many ebb-tidal deltas have periodic shifting between one and two channels in the inlet, channel deflection and/or development of a large sandy shoal. This study reveals the patterns of wave energy, tidal currents and sediment transport during four phases of this cyclic behavior. Because it identifies and qualitatively evaluates the response of these physical processes to distinct bathymetries, the outcomes contribute to our understanding of the complex interaction between the hydrodynamics and sediment dynamics at natural tidal inlets.

Acknowledgements We thank Rijkswaterstaat for making their bathymetric and wave data available. We would like to thank J.A. Lenstra for the critical reading. Also thanks to S.G. Pearson for the helpful suggestions. We thank the anonymous reviewers for their valuable comments and suggestions.

Funding information Funded by the Netherlands Organisation for Scientific Research (NWO) (project 869.15.009).

Open Access This article is distributed under the terms of the Creative Commons Attribution 4.0 International License (http:// creativecommons.org/licenses/by/4.0/), which permits unrestricted use, distribution, and reproduction in any medium, provided you give appropriate credit to the original author(s) and the source, provide a link to the Creative Commons license, and indicate if changes were made.

\section{References}

Booij N, Ris R, Holthuijsen LH (1999) A third-generation wave model for coastal regions: 1 . model description and validation. J Geophys Res Oceans 104(C4):7649-7666

Cayocca F (2001) Long-term morphological modeling of a tidal inlet: the arcachon basin, France. Coast Eng 42(2):115-142

Cheung KF, Gerritsen F, Cleveringa J (2007) Morphodynamics and sand bypassing at Ameland Inlet, the Netherlands. J Coast Res 23(1):106-118

De Fockert A (2008) Impact of relative sea level rise on the Amelander Inlet Morphology. Master's thesis. TU Delft, Delft University of Technology 
De Swart HE, Zimmerman JTF (2009) Morphodynamics of tidal inlet systems. Ann Rev Fluid Mech 41:203-229

Deltares (2009) Sbw wadden sea, water level modelling-calibration hydrodynamic model. delft, Deltares Report pp 1200114-005

Deltares (2014) Simulation of multi-dimensional hydrodynamic flows and transport phenomena, including sediments. User Manual Delft3D-FLOW, the Netherlands, 690

Dissanayake DMPK, Ranasinghe R, Roelvink JA (2012) The morphological response of large tidal inlet/basin systems to relative sea level rise. Clim Chang 113(2):253-276

Elias E, Teske R, Van der Spek A, Lazar M (2015) Modelling tidal-inlet morphodynamics on medium time scales. In: The Proceedings of the coastal sediments 2015. World Scientific

Elias EP, Hansen JE (2013) Understanding processes controlling sediment transports at the mouth of a highly energetic inlet system (san francisco bay, ca). Mar Geol 345:207-220

Elias EPL, Van der Spek AJF, Wang ZB, De Ronde J (2012) Morphodynamic development and sediment budget of the dutch wadden sea over the last century. Neth J Geosci 91(03):293310

Fitzgerald DM (1984) Interactions between the ebb-tidal delta and landward shoreline: price inlet, South Carolina. J Sediment Res 54(4):1303-1318

FitzGerald DM (1988) Shoreline erosional-depositional processes associated with tidal inlets. In: Hydrodynamics and sediment dynamics of tidal inlets, Springer, pp 186-225

FitzGerald DM, Kraus NC, Hands EB (2000) Natural mechanisms of sediment bypassing at tidal inlets. Tech. rep., DTIC Document

Friedrichs CT, Aubrey DG (1988) Non-linear tidal distortion in shallow well-mixed estuaries: a synthesis. Estuar Coast Shelf Sci 27(5):521-545

Hansen JE, Elias E, Barnard PL (2013) Changes in surfzone morphodynamics driven by multi-decadal contraction of a large ebb-tidal delta. Mar Geol 345:221-234

Hayes MO (1975) Morphology of sand accumulation in estuaries: an introduction to the symposium. Estuarine Research 2:3-22

Herrling G, Winter C (2014) Morphological and sedimentological response of a mixed-energy barrier island tidal inlet to storm and fair-weather conditions. Earth Surf Dyn 2(1):363-382

Holthuijsen LH (2010) Waves in Oceanic and Coastal Waters. Cambridge University Press, Cambridge

Isobe M, Horikawa K (1982) Study on water particle velocities of shoaling and breaking waves. Coast Eng Jpn 25(1):109-123

Israel CG, Dunsbergen DW (1999) Cyclic morphological development of the Ameland Inlet, the Netherlands. In: Proceedings IAHR Symposium on river, coastal and estuarine morphodynamics, Department of Environmental Engineering, University of Genoa, pp 705-714

Jiao J (2014) Morphodynamics of ameland inlet: medium-term delft3d modelling

Kleinhans MG, Van Scheltinga RT, Van Der Vegt M, Markies H (2015) Turning the tide: growth and dynamics of a tidal basin and inlet in experiments. J Geophys Res Earth Surf 120(1):95-119

Latteux B (1995) Techniques for long-term morphological simulation under tidal action. Mar Geol 126(1-4):129-141
Nahon A, Bertin X, Fortunato AB, Oliveira A (2012) Process-based 2 dh morphodynamic modeling of tidal inlets: a comparison with empirical classifications and theories. Mar Geol 291:1-11

Ridderinkhof H (1988) Tidal and residual flows in the western dutch wadden sea i: numerical model results. Neth J Sea Res 22(1):1-21

Ridderinkhof W, De Swart HE, van der Vegt M, Hoekstra P (2014) Geometry of tidal inlet systems: a key factor for the net sediment transport in tidal inlets. J Geophys Res Oceans 119(10):6988-7006

Ridderinkhof W, De Swart HE, van der Vegt M, Hoekstra P (2014) Influence of the back-barrier basin length on the geometry of ebb-tidal deltas. Ocean Dyn 64(9):1333-1348

Ridderinkhof W, Hoekstra P, van der Vegt M, De Swart HE (2016) Cyclic behavior of sandy shoals on the ebb-tidal deltas of the wadden sea. Cont Shelf Res 115:14-26

Ridderinkhof W, Swart H, van der Vegt M, Hoekstra P (2016) Modeling the growth and migration of sandy shoals on ebb-tidal deltas. J Geophys Res Earth Surf 121(7):1351-1372

Ris R, Holthuijsen L, Booij N (1999) A third-generation wave model for coastal regions: 2. verification. J Geophys Res Oceans 104(C4):7667-7681

Roelvink J, Walstra DJ (2004) Keeping it simple by using complex models. Advances in Hydro-science and Engineering 6:1-11

Sha LP (1989) Variation in ebb-delta morphologies along the West and East Frisian Islands, The Netherlands and Germany. Mar Geol 89(1):11-28

Soulsby R, Davies A, Fredsøe J, Huntley D, Jonsson I, Myrhaug D, Simons R, Temperville A, Zitman T (1993) Bed shear-stresses due to combined waves and currents. book of abstracts, mast- $2, \mathrm{~g} 8 \mathrm{~m}$ coastal morphodynamics. In: Overall workshop, grenoble, pp 2-1

Speer P, Aubrey D (1985) A study of non-linear tidal propagation in shallow inlet/estuarine systems part ii: Theory. Estuar Coast Shelf Sci 21(2):207-224

Van Leeuwen S, Van der Vegt M, De Swart H (2003) Morphodynamics of ebb-tidal deltas: a model approach. Estuar Coast Shelf Sci 57(5):899-907

Van Rijn L, Walstra D, Ormondt MV (2004) Description of transpor2004 and implementation in delft3d-online: final report. Tech. rep., Deltares (WL)

Van Rijn LC (2007) Unified view of sediment transport by currents and waves. i: Initiation of motion, bed roughness, and bed-load transport. J Hydraul Eng 133(6):649-667

Van Rijn LC (2007) Unified view of sediment transport by currents and waves. waves. ii: Suspended transport. J Hydraul Eng 133(6):668689

Van der Vegt M, Schuttelaars H, De Swart H (2009) The influence of tidal currents on the asymmetry of tide-dominated ebb-tidal deltas. Cont Shelf Res 29(1):159-174

Van der Vegt M, Schuttelaars HM, De Swart HE (2006) Modeling the equilibrium of tide-dominated ebb-tidal deltas. J Geophys Res Earth Surf 111(F2):2003-2012

Wang Y, Yu Q, Jiao J, Tonnon PK, Wang ZB, Gao S (2016) Coupling bedform roughness and sediment grain-size sorting in modelling of tidal inlet incision. Mar Geol 381:128-141

Van der Westhuysen AJ (2012) Spectral modeling of wave dissipation on negative current gradients. Coast Eng 68:17-30 